\title{
Therapeutic effect of cimetidine in patients undergoing haemodialysis
}

\author{
R H JONES M R LEWIN, V PARSONS
}

British Medical fournal, 1979, 1, 650-652

\section{Summary and conclusions}

Blood concentrations of cimetidine were measured and the therapeutic effect of the drug assessed in patients undergoing maintenance haemodialysis. Thirteen patients were given a single oral $200-\mathrm{mg}$ dose of cimetidine a mean of 2.7 hours before the start of dialysis. Dialysing for 6-12.6 $\mathrm{m}^{2}$ hours led to a mean fall of $71 \%$ in blood cimetidine concentration during haemodialysis. Nine patients with various upper gastrointestinal lesions diagnosed endoscopically were treated for up to six weeks with a reduced cimetidine dose of $200 \mathrm{mg} \mathrm{12}$ hourly; two patients received two courses of treatment. Repeat endoscopy after treatment disclosed satisfactory healing, and the drug did not accumulate.

This lower dose regimen is recommended for patients receiving dialysis who develop upper gastrointestinal lesions for which a histamine $\mathbf{H}_{2}$-receptor antagonist is indicated.

\section{Introduction}

Evidence concerning the incidence of peptic ulceration in uraemic patients receiving dialysis is conflicting. ${ }^{1-5}$ Radiological criteria for this may be unreliable. ${ }^{6}$ Other gastrointestinal lesions may occur, including hiatus hernia with gastrooesophageal reflux in patients with polycystic disease ${ }^{7}$ and acute gastrointestinal erosions. Excess gastric-acid secretion has been confirmed ${ }^{3} 8$ and refuted $^{2}$ in these patients, and

\footnotetext{
King's College Hospital Renal Unit, Dulwich Hospital, London SE22

R H JONES, MA, MRCP, research fellow

V PARSONS, DM, FRCP, consultant physician

Surgical Unit, University College Hospital Medical School, London WC1

M R LEWIN, BSC, PHD, research fellow
}

hypergastrinaemia may occur. ${ }^{9-11}$ High concentrations of parathyroid hormone, which may be implicated in peptic ulceration, ${ }^{12} 13$ are common in end-stage renal failure. ${ }^{14}$ Gastric acid and histamine are important in the development of many of these lesions, ${ }^{15-19}$ and a bleeding diathesis in uraemic patients $^{20}$ may contribute to gastrointestinal haemorrhage. Using histamine $\mathrm{H}_{2}$-receptor antagonists improves the symptoms and hastens healing of peptic oesophagitis, ${ }^{21}$ gastric ulcer, ${ }^{22}$ and duodenal ulcer, ${ }^{23}{ }^{24}$ even in patients receiving dialysis. ${ }^{25}$ Cimetidine is excreted by the kidney, largely unchanged, ${ }^{26}$ and some side effects ${ }^{2728}$ may be related to accumulation. We have tested the clearance of cimetidine given to patients receiving dialysis, altered the usual dose regimen accordingly, and assessed its therapeutic effect in patients with peptic lesions receiving haemodialysis.

\section{Patients and methods}

We studied two groups of patients-namely, 13 "fit" patients undergoing maintenance haemodialysis and eight patients with evidence of upper gastrointestinal peptic lesions. All gave their informed consent to the study. The initial 13 patients were studied in order to determine the effect of haemodialysis on blood concentrations of cimetidine. Each patient received a 200-mg dose of cimetidine by mouth on the morning of the dialysis day, having received the same dose 12 hours before. The times of drug administration and blood sampling at the beginning and end of dialysis were recorded. Heparinised blood was stored at $-20^{\circ} \mathrm{C}$ until the cimetidine concentrations were measured ${ }^{29}$ (table I).

The eight patients with evidence of gastrointestinal peptic lesions, two of whom received two separate courses of treatment (table II), were studied to assess the therapeutic effect of cimetidine. Upper gastrointestinal fibreoptic endoscopy, using an Olympus GFK-2 oblique-viewing panendoscope, was performed in all patients at the beginning of the course and in all but two at the end. The indications for this investigation were anaemia, abdominal pain, and upper gastrointestinal haemorrhage (table III). Barium-meal examination was performed in all but two cases (1 and 3); in these a firm endoscopic diagnosis was made after haematemesis and melaena. Cimetidine, $200 \mathrm{mg}$ each morning and evening after dialysis, was started within two days of the endoscopic diagnosis and continued for up to six weeks. Drug concentrations were measured as above, while symptomatic, haematological, and biochemical assessments

TABLE I-Cimetidine concentrations before and after haemodialysis and details of dialysis

\begin{tabular}{|c|c|c|c|c|c|c|c|}
\hline \multirow[b]{2}{*}{$\begin{array}{l}\text { Case } \\
\text { No }\end{array}$} & \multirow[b]{2}{*}{ Dialyser } & \multirow{2}{*}{$\begin{array}{c}\text { Duration of } \\
\text { haemodialysis } \\
\text { (hours) }\end{array}$} & \multirow{2}{*}{$\begin{array}{r}\mathrm{m}^{2} \text { hours of } \\
\text { dialysis/week }\end{array}$} & \multirow{2}{*}{$\begin{array}{l}\text { Time between } \\
\text { ingestion of } \\
\text { cimetidine and } \\
\text { predialysis blood } \\
\text { sample (hours) }\end{array}$} & \multicolumn{2}{|c|}{ Cimetidine concentration (mg/l) } & \multirow{2}{*}{$\begin{array}{l}\text { Percentage fall } \\
\text { during dialysis }\end{array}$} \\
\hline & & & & & Before dialysis & After dialysis & \\
\hline $\begin{array}{l}\mathrm{A} \\
\mathrm{B} \\
\mathrm{C} \\
\mathrm{D} \\
\mathrm{E}\end{array}$ & $\begin{array}{l}1 \mathrm{~m}^{2} \mathrm{Kiil} \\
1 \mathrm{~m}^{2} \mathrm{Kiil} \\
1 \mathrm{~m}^{2} \mathrm{Kiil} \\
1.4 \mathrm{~m}^{2} \mathrm{Kiil} \\
\text { Travenol } 1.4 \mathrm{~m}^{2} \\
\text { coil }\end{array}$ & $\begin{array}{l}9 \\
9 \\
7 \\
9 \\
6\end{array}$ & $\begin{array}{r}9 \cdot 0 \\
9 \cdot 0 \\
7 \cdot 0 \\
12 \cdot 6 \\
8 \cdot 4\end{array}$ & $\begin{array}{l}2 \cdot 6 \\
3 \cdot 6 \\
4 \cdot 0 \\
2 \cdot 6 \\
3 \cdot 0\end{array}$ & $\begin{array}{l}1.9 \\
3.9 \\
1.6 \\
2.3 \\
1.8\end{array}$ & $\begin{array}{l}0.2 \\
1.9 \\
0.4 \\
0.5 \\
0.5\end{array}$ & $\begin{array}{l}89 \\
51 \\
75 \\
78 \\
72\end{array}$ \\
\hline \multirow[t]{2}{*}{$\begin{array}{l}\mathrm{F} \\
\mathrm{G} \\
\mathrm{H} \\
\mathrm{I} \\
\mathrm{J} \\
\mathrm{K} \\
\mathrm{L} \\
\mathrm{M}\end{array}$} & $\begin{array}{l}1 \mathrm{~m}^{2} \mathrm{Kiil} \\
1 \mathrm{~m}^{2} \mathrm{Kiil} \\
1 \mathrm{~m}^{2} \mathrm{Kiil} \\
\mathrm{Tri-Ex} \\
1 \mathrm{~m}^{2} \mathrm{Kiil} \\
1 \mathrm{~m}^{2} \mathrm{Kiil} \\
\text { Tri-Ex } \\
\text { Tri-Ex }\end{array}$ & $\begin{array}{l}9 \\
9 \\
8 \\
7 \\
9 \\
6 \\
7 \\
7\end{array}$ & $\begin{array}{l}9 \cdot 0 \\
9 \cdot 0 \\
8 \cdot 0 \\
7 \cdot 0 \\
9 \cdot 0 \\
6 \cdot 0 \\
7 \cdot 0 \\
7 \cdot 0\end{array}$ & $\begin{array}{l}3 \cdot 0 \\
2 \cdot 0 \\
2 \cdot 3 \\
1 \cdot 1 \\
2 \cdot 8 \\
2 \cdot 4 \\
2 \cdot 2 \\
2 \cdot 2\end{array}$ & $\begin{array}{l}1.8 \\
2.5 \\
3 \cdot 1 \\
2 \cdot 3 \\
2 \cdot 0 \\
2.5 \\
1.6 \\
1.9\end{array}$ & $\begin{array}{l}0.3 \\
0.5 \\
1.4 \\
0.7 \\
0.8 \\
1.0 \\
0.3 \\
0.5\end{array}$ & $\begin{array}{l}83 \\
76 \\
55 \\
69 \\
60 \\
60 \\
81 \\
73\end{array}$ \\
\hline & Mean \pm SD & $7 \cdot 85 \pm 1 \cdot 21$ & $8.31 \pm 1.66$ & $2.68 \pm 0.73$ & $2 \cdot 22 \pm 0.65$ & $0.69 \pm 0.49$ & $70 \cdot 92 \pm 11 \cdot 42$ \\
\hline
\end{tabular}


TABLE II-Details of patients in therapeutic study

\begin{tabular}{|c|c|c|c|c|c|c|c|c|}
\hline $\begin{array}{l}\text { Case } \\
\text { No }\end{array}$ & Sex & Age & Blood group & Cause of renal failure & Other details & $\begin{array}{c}\text { Time on } \\
\text { haemodialysis }\end{array}$ & $\begin{array}{l}\text { Weekly dialysis } \\
\text { schedule during } \\
\text { treatment }\end{array}$ & $\begin{array}{c}\mathrm{m}^{2} \text { hours } \\
\text { of dialysis/ } \\
\text { week }\end{array}$ \\
\hline $\begin{array}{l}1 \\
2\end{array}$ & $\stackrel{\mathrm{M}}{\mathrm{F}}$ & $\begin{array}{l}36 \\
25\end{array}$ & $\begin{array}{l}\mathrm{A} \\
\mathrm{O}\end{array}$ & $\begin{array}{l}\text { Hypertension } \\
\text { Hypertension }\end{array}$ & $\begin{array}{l}\text { Anephric } \\
\text { Failing renal }\end{array}$ & 1 month & 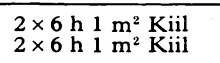 & $\begin{array}{l}12 \\
12\end{array}$ \\
\hline 3 & $M$ & 29 & B & Spina bifida & $\begin{array}{l}\text { transplant } \\
\text { Anephric }\end{array}$ & 7 years & $\begin{array}{l}3 \times 7 \mathrm{~h} 1 \mathrm{~m}^{2} \text { Cordis } \\
\text { Dow Hollow }\end{array}$ & 21 \\
\hline $4^{*}$ & $\begin{array}{l}M \\
M\end{array}$ & $\begin{array}{l}54 \\
27\end{array}$ & $\begin{array}{l}\mathrm{O} \\
\mathrm{AB}\end{array}$ & $\begin{array}{l}\text { Polycystic kidneys } \\
\text { Glomerulonephritis after } \\
\text { streptococcal infection }\end{array}$ & $\begin{array}{l}\text { Anephric } \\
\text { Anephric }\end{array}$ & $\begin{array}{l}3 \text { years } \\
8 \text { years }\end{array}$ & $\begin{array}{l}\text { Fibre } \\
2 \times 8 \mathrm{hh} \quad \mathrm{m}^{2} \text { Kiil } \\
2 \times 6 \mathrm{~h} \quad \mathrm{~m}^{2} \mathrm{Kiil}\end{array}$ & $\begin{array}{l}16 \\
12\end{array}$ \\
\hline $6^{*}$ & $M$ & 50 & $\mathrm{O}$ & ?Glomerulonephritis & $\begin{array}{l}\text { Previous partial } \\
\text { gastrectomy }\end{array}$ & 1 week & $2 \times 8 \mathrm{~h}^{1 \mathrm{~m}^{2} \mathrm{Kiil}}$ & 16 \\
\hline $\begin{array}{c}7 \\
8 \\
9 * \\
10^{*}\end{array}$ & $\begin{array}{l}F \\
M \\
M \\
M\end{array}$ & $\begin{array}{l}28 \\
36 \\
54 \\
50\end{array}$ & $\begin{array}{l}\mathrm{O} \\
\mathrm{A} \\
\mathrm{O} \\
\mathrm{O}\end{array}$ & $\begin{array}{l}\text { Diabetes mellitus } \\
\text { Hypertension } \\
\text { Polycystic kidneys } \\
\text { ?Glomerulonephritis }\end{array}$ & $\begin{array}{l}\text { Anephric } \\
\text { Previous partial } \\
\text { gastrectomy }\end{array}$ & $\begin{array}{l}1 \text { year } \\
1 \text { month } \\
3 \text { years } \\
6 \text { months }\end{array}$ & 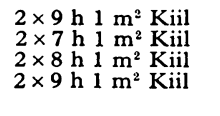 & $\begin{array}{l}18 \\
14 \\
16 \\
18\end{array}$ \\
\hline
\end{tabular}

${ }^{*}$ Cases 4 and 9 , and 6 and 10, refer to two patients who each received two separate courses of treatment.

TABLE III-Results of investigations carried out in therapeutic study

\begin{tabular}{|c|c|c|c|c|c|c|}
\hline $\begin{array}{l}\text { Case } \\
\text { No }\end{array}$ & Clinical problem & Barium-meal examination & $\begin{array}{l}\text { Fasting gastrin } \\
\text { concentration } \\
(\mathrm{ng} / \mathrm{l})\end{array}$ & Diagnostic endoscopy & Repeat endoscopy & Comments \\
\hline 1 & $\begin{array}{l}\text { Massive gastrointestinal } \\
\text { haemorrhage }\end{array}$ & Not done & 188 & Acute duodenal ulcer & Normal & $\begin{array}{l}\text { Received transplant after } \\
3 \text { weeks' treatment }\end{array}$ \\
\hline 2 & Anaemia & Normal & 77 & $\begin{array}{l}\text { Oesophagitis, gastric } \\
\text { erosions }\end{array}$ & Normal & $\begin{array}{l}3 \text { weeks' treatment } \\
\text { Also treated with } \\
\text { flucytosine (Candida } \\
\text { spp in oesophagus) }\end{array}$ \\
\hline 3 & $\begin{array}{l}\text { Haematemesis and } \\
\text { melaena }\end{array}$ & Not done & 134 & $\begin{array}{l}\text { Multiple gastric } \\
\text { erosions }\end{array}$ & Normal & \\
\hline $\begin{array}{l}4 \\
5\end{array}$ & $\begin{array}{l}\text { Anaemia } \\
\text { Vomiting and } \\
\text { postprandial pain }\end{array}$ & $\begin{array}{l}\text { Sliding hiatus hernia } \\
\text { Small sliding hiatus } \\
\text { hernia }\end{array}$ & $\begin{array}{r}120 \\
76\end{array}$ & $\begin{array}{l}\text { Oesophagitis } \\
\text { Oesophagitis }\end{array}$ & $\begin{array}{l}\text { Normal } \\
\text { Normal }\end{array}$ & $\begin{array}{l}\text { Symptomatic } \\
\text { improvement }\end{array}$ \\
\hline 6 & Anaemia & $\begin{array}{l}\text { "Shaggy" lower } \\
\text { oesophagus }\end{array}$ & 62 & Oesophagitis & Normal & $\begin{array}{l}\text { Also treated with } \\
\text { miconazole (Candida } \\
\text { spp in oesophagus) }\end{array}$ \\
\hline 7 & Retrosternal pain & $\begin{array}{l}\text { Gastro-oesophageal } \\
\text { reflux }\end{array}$ & 124 & Oesophagitis & $\begin{array}{l}\text { Normal upper } \\
\text { gastrointestinal tract } \\
\text { at postmortem } \\
\text { examination }\end{array}$ & $\begin{array}{l}\text { Sudden death after } \\
1 \text { month's treatment }\end{array}$ \\
\hline 8 & $\begin{array}{l}\text { History of duodenal } \\
\text { ulcer: awaiting renal } \\
\text { transplant }\end{array}$ & Scarred duodenal cap & 158 & Chronic duodenal ulcer & Some duodenitis & $\begin{array}{l}\text { Received transplant } \\
\text { after } 3 \text { weeks' } \\
\text { treatment }\end{array}$ \\
\hline 9 & Haematemesis & $\begin{array}{l}\text { Hiatus hernia with } \\
\text { gastro-oesophageal } \\
\text { reflux }\end{array}$ & 120 & $\begin{array}{l}\text { Oesophagitis with } 3 \\
\text { acute Barret's ulcers }\end{array}$ & Not performed & $\begin{array}{l}\text { Died (after cimetidine } \\
\text { stopped) }\end{array}$ \\
\hline 10 & Abdominal pain & Normal & 62 & Gastritis around stoma & Slight inflammation only & $\begin{array}{c}\text { Symptomatic } \\
\text { improvement }\end{array}$ \\
\hline
\end{tabular}

were carried out weekly. Fasting serum gastrin concentrations before dialysis were measured by radioimmunoassay (CIS-GASK, Eurotope Services Ltd, London), based on the method described by Berson and Yalow. ${ }^{30}$

All results were expressed as means $\pm \mathrm{SD}$.

\section{Results}

In the 13 patients in the first part of the study the percentage fall in cimetidine concentration during haemodialysis was $70.92 \pm 11.42 \%$, with mean concentrations before and after dialysis of $2 \cdot 22 \pm 0.65 \mathrm{mg} / \mathrm{l}$ and $0.69 \pm 0.49 \mathrm{mg} / 1$ respectively (table I). The figure shows the change in concentration in each patient.

In the therapeutic study endoscopy was repeated after treatment in eight cases and showed satisfactory resolution of the lesions; it was not performed in cases 7 and 9 , in which the patients died during the period of treatment (table III). Not all of the remaining patients completed the six-week course. In cases 1 and 8 the patients received renal transplants after three weeks of treatment, though they continued to take cimetidine after transplantation. Both underwent endoscopy at the time of transplantation, which showed that their lesions had healed. The patients in cases 2 and 6 , in whom oesophageal smears taken at ndoscopy contained Candida spp, received flucytosine ${ }^{31}$ and miconazole 32 in addition to cimetidine. Symptomatic improvement occurred after two weeks in the patients in cases 5 and 10; none of the other patients had symptoms initially. Table III shows the fasting serum gastrin concentrations. The mean value was $112 \cdot 1 \pm 42 \cdot 4 \mathrm{ng} / \mathrm{l}$, which is significantly $(\mathbf{P}<0.002)$ higher than the normal for this assay $(50 \cdot 8 \pm 12 \cdot 3 \mathrm{ng} / \mathrm{l})$.

Table IV shows the mean weekly blood concentrations of cimetidine before and after haemodialysis for all patients. Concentrations before dialysis ranged from $1 \cdot 1$ to $4.0 \mathrm{mg} / 1$ and those after dialysis from

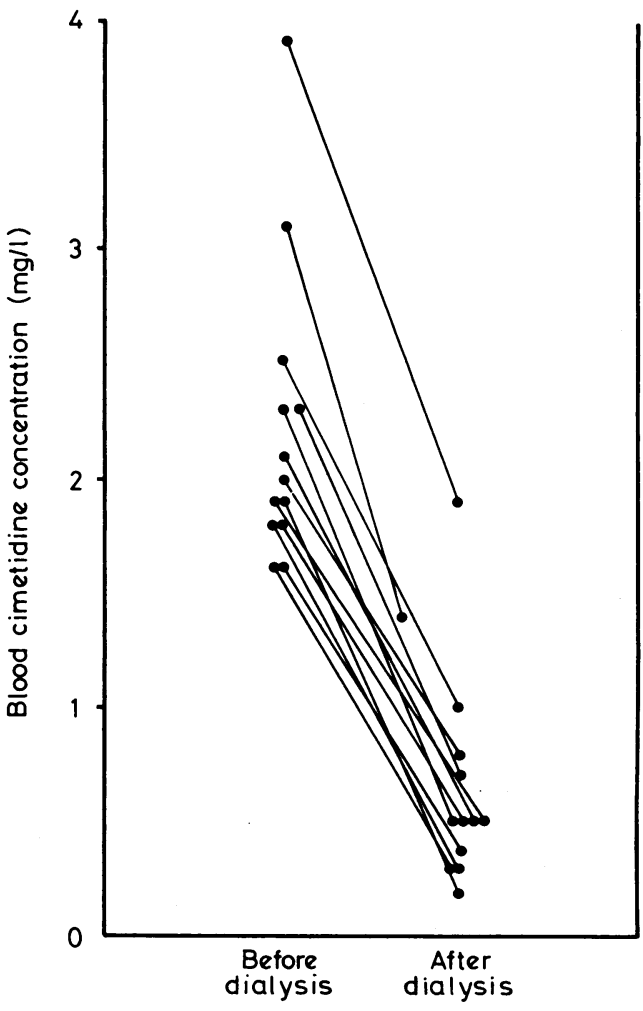

Cimetidine concentrations before and after dialysis in the 13 patients studied. 
TABLE IV--Mean $( \pm S E$ of mean) weekly cimetidine concentrations $(m g / l)$ before and after dialysis

\begin{tabular}{|c|c|c|c|c|c|c|}
\hline No of weeks of treatment: & 1 & 2 & 3 & 4 & 5 & 6 \\
\hline $\begin{array}{ll}\text { Before dialysis } \ldots & \ldots \\
\text { After dialysis } & .\end{array}$ & $\begin{array}{l}2 \cdot 2 \pm 0 \cdot 4 \\
0 \cdot 7 \pm 0 \cdot 2\end{array}$ & $\begin{array}{l}2 \cdot 2=0.65 \\
1 \cdot 1=0.3\end{array}$ & $\begin{array}{l}2 \cdot 2 \pm 0.55 \\
1 \cdot 4=0.3\end{array}$ & $\begin{array}{l}2 \cdot 6-0.6 \\
0.7+0.25\end{array}$ & $\begin{array}{l}1 \cdot 5 \pm 0 \cdot 6 \\
0 \cdot 7 \div 0 \cdot 2\end{array}$ & $\begin{array}{l}1 \cdot 8 \pm 0.5 \\
0.9 \pm 0.3\end{array}$ \\
\hline
\end{tabular}

0 to $1.7 \mathrm{mg} / \mathrm{l}$, with mean values over the entire course of treatment of $2.1 \pm 1.33$ and $0.9 \pm 0.62 \mathrm{mg} / 1$ respectively. The mean percentage fall in cimetidine concentration during haemodialysis was $59 \%$ (range $50-73 \%$ ).

No adverse change in any of the haematological or biochemical indices was seen, and the drug was well tolerated. Vomiting occurred after two weeks' treatment in case 7 and ceased when several drugs, including cimetidine, were discontinued; cimetidine was started again without further vomiting.

\section{Discussion}

This study has shown that cimetidine is well absorbed in uraemic patients receiving dialysis, in whom therapeutic effect is achieved without accumulation or undesirable actions at a dosage of $200 \mathrm{mg}$ 12-hourly. Clearly from our results complete clearance of cimetidine from the blood does not occur with several dialysers. These findings differ from those of Canavan ar ${ }_{\perp}$ Briggs, ${ }^{29}$ who found complete clearance of cimetidine during haemodialysis. In all cases blood concentrations were within the therapeutic range. After dialysis a concentration above $0.5 \mathrm{mg} / \mathrm{l}$, which reduces histamine- and pentagastrin-stimulated secretion of gastric acid by $50^{\circ} \mathrm{o}^{33}$ was found in nine of the 13 patients in the pharmacokinetic study (mean $0.9 \mathrm{mg} / \mathrm{l}$ ). The two patients with the highest gastrin concentrations developed duodenal ulceration, having both received haemodialysis (which does not appreciably alter serum gastrin concentrations ${ }^{9}$ ) for one month only.

Cimetidine was therapeutically effective in this group of uraemic patients with a range of upper gastrointestinal lesions, despite the multiple mechanisms at play. Endoscopy disclosed adequate healing; cimetidine effectively relieved the symptoms of pain in two patients, and two patients were safely transplanted within three weeks after diagnosis of duodenal ulceration without gastric surgery. Two patients developed recurrences after having received no treatment for several months: the patient in case 9 became severely ill with septicaemia when haematemesis occurred and died after a cerebral haemorrhage, while the patient in case 10 was symptom free for five months before developing abdominal pain due to gastritis.

No unexplained changes in haematological or biochemical indices or side effects were seen. We therefore recommend cimetidine $200 \mathrm{mg}$ 12-hourly for patients receiving maintenance haemodialysis with peptic lesions for whom a histamine $\mathrm{H}_{2}-$ receptor antagonist is indicated.

We should like to thank the nursing staff of the renal unit for their invaluable help; the clinical research group, Smith Kline and French, for their help in monitoring the studies; and the biochemistry department at Smith Kline and French for assaying the cimetidine.

\section{References}

${ }^{1}$ Comty, C M, Baillod, R A, and Shaldon, S, Proceedings of the European Dialysis and Transplant Association, 1965, 2, 88.

2 Chisholm, G D, et al, British Medical fournal, 1977, 1, 1630

3 Gordon, E M, Johnson, A G, and Williams, G, Lancet, 1972, 2, 226

4 Langman, M J S, and Cooke, A P, Lancet, 1976, 1, 680.

5 Shepherd, A M M, Stewart, W K, and Wormsley, K G, Lancet, 1973, $1,1357$.

6 Wieners, S N, Veacs, V, and Shapiro, H, Radiology, 1969, 92, 110

7 Bailey, G L, et al, American Society of Nephrologists 5th Annual Meeting, 1971, abstracts, p 5.

${ }^{8}$ Shepherd, A M M, et al, British Medical fournal, 1974, 1, 96.
${ }^{9}$ Korman, M G, Laver, M C, and Hansky, J, British Medical fournal, 1972, 1, 209.

10 Clendinnen, B G, et al, Gut, 1973, 14, 462.

11 Sullivan, S N, et al, Clinical Nephrology, 1976, 5, 25.

12 St Goar, W T, Annals of Internal Medicine, 1957, 46, 102.

13 Kaplan, E L, et al, fournal of Surgical Research, 1972, 12, 229

${ }^{14}$ Katz, A I, Hampers, C L, and Merrill, J P, Medicine, 1969, 48, 333.

15 MacDougall, B R D, Bailey, R J, and Williams, R, Lancet, 1977, 1, 617.

${ }_{16}$ Moody, F G, et al, American fournal of Digestive Diseases, 1976, 21, 148.

17 Johnson, L R, Gastroenterology, 1968, 54, 8.

\& Davenport, H W, in Progress of Gastroenterology, vol 2, ed G Jerzy-Glass, p 42. New York, Grune and Stratton, 1970.

19 Moore, T C, Thompson, D F, and Glassock, R J, Annals of Surgery, $1971,173,381$.

${ }^{20}$ Riesman, D, American fournal of Medical Science, 1907, 134, 709.

${ }^{21}$ McCluskie, R A, et al, in Cimetidine, ed W R Burland and M A Simkins, p 297. Amsterdam, Excerpta Medica, 1977.

${ }^{22}$ Frost, F, et al, British Medical fournal, 1977, 2, 795

${ }^{23}$ Bodemar, G, and Walan, A, Lancet, 1976, 2, 161.

${ }^{24}$ Gray, G R, et al, Lancet, 1977, 1, 4.

${ }^{25}$ Doherty, C C, et al, British Medical fournal, 1977, 2, 1506.

${ }^{26}$ Griffiths, R, Lee, R M, and Taylor, D C, in Cimetidine, ed W R Burland and M A Simkins, p 38. Amsterdam, Excerpta Medica, 1977.

${ }_{27}$ Delaney, J C, and Ravey, M, Lancet, 1977, 2, 512.

${ }^{28}$ Grimson, T A, Lancet, 1977, 1, 858.

29 Canavan, J S F, and Briggs, J D, in Cimetidine, ed W R Burland and M A Simkins, p 75. Amsterdam, Excerpta Medica, 1977.

${ }^{30}$ Berson, S, and Yalow, R S, Gastroenterology, 1970, 58, 1.

${ }^{31}$ Vandevelde, A G, Mauceri, A A, and Johnson, J E, Annals of Internal Medicine, 1972, 77, 43.

${ }^{32}$ Van Cutsem, J M, and Thienpoint, D, Chemotherapy, 1972, 17, 392.

${ }^{33}$ Burland, W L, et al, British fournal of Clinical Pharmacology, 1975, 2, 481

(Accepted 11 fanuary 1979)

ONE HUNDRED YEARS AGO Perhaps the following incident may be of interest to your readers, showing as it does the antidotal power of chloral in combating the poisonous effects of strychnia. About three years ago, my pet dog, a small toy terrier (Skye) was very unwell, apparently with some sort of indigestion. After trying various remedies and diets, I determined to give him a very minute dose of nux vomica, having experienced myself its beneficial effects when troubled with dyspepsia caused by sedentary habits. When I came to this decision, I had forgotten for the moment that strychnia in all forms is a most virulent poison to dogs. I gave my pet, early one morning, a pill containing a quarter of a grain of extract of nux vomica, then had my breakfast, and went off to business, about three-quarters of a mile from my residence. I had not been in my office ten minutes, when a maid-servant came running into the place, and said "Please, sir, come home at once, the dog has gone mad." In a moment, it flashed on my mind what had caused the attack, and I at once made my way home. On arriving, I was told that the dog had run into the garden at the back of the house. I went there, and found the dog running about wildly, knocking himself against anything that stood in his way, and occasionally falling into paroxysms, during which the dog's body was stiff, eyes staring, and teeth clenched. Between the attacks, the dog recognised me. For a moment, I felt nonplussed, and I found it impossible to make the dog sick, and if I had done so, I doubt if it would have been of much use; so, as a dernier ressort, I administered, with much trouble, a teaspoon of syrup of chloral, which fortunately I had in the house, in a tablespoonful of warm water. The spasms almost immediately ceased, and in half an hour, I left home for business again, after putting the patient comfortably in a hamper. When I returned home at mid-day, the dog was sleeping quietly, and towards night was all right again, although the eyes were rather dull. The patient soon was as lively as ever, and is now well and hearty, and likes his master better than ever. (British Medical fournal, 1879.) 